\title{
ROLE OF CONCENTRATED FLOW PATHWAYS ON THE MOVEMENT OF PESTICIDES THROUGH AGRICULTURAL FIELDS AND RIPARIAN BUFFER ZONES
}

\author{
Joseph W. Chandler1, Heather E. Preisendanz ${ }^{1, *}$, Tamie L. Veith², Kyle R. Elkin², \\ Herschel A. Elliott ${ }^{1}$, John E. Watson ${ }^{1}$, Peter J. A. Kleinman ${ }^{2}$ \\ ${ }^{1}$ Department of Agricultural and Biological Engineering, The Pennsylvania State University, University Park, Pennsylvania, USA. \\ ${ }^{2}$ USDA-ARS Pasture Systems and Watershed Management Research Unit, University Park, Pennsylvania, USA. \\ * Correspondence: hpreisen@psu.edu.
}

\section{HIGHLIGHTS}

- Land management and hydrologic connectivity cause concentrated flow pathways (CFPs) to serve various functions.

- Pesticide concentrations diminished along flow pathways from row-cropped fields through functional riparian zones.

- CFPs facilitated pesticide transport into pasture/hay fields from upgradient corn fields.

- Subsurface transport was likely a more important transport pathway relative to surface runoff for imidacloprid.

\begin{abstract}
Riparian buffers, which are an important component of watershed management strategies, can effectively mitigate nutrients and pesticides in agricultural runoff. However, concentrated flow pathways (CFPS) can undermine the performance of buffers by allowing contaminant-laden runoff to bypass the mitigation potential offered by the buffer soils and vegetation. To determine the extent to which CFPs increase pesticide transport from agricultural fields to nearby streams, soil samples (0-2 cm depth) were collected along both CFPs and overland flow (OLF) pathways from the field to the stream for nine fields in a Long-Term Agroecosystem Research (LTAR) site in the ridge and valley physiographic region of Pennsylvania. Soil samples were analyzed for atrazine, metolachlor, and imidacloprid, with two dominant patterns emerging. In corn fields, pesticide concentrations were higher in OLF than CFP samples, suggesting that pesticides were mitigated during transport through each corn field. In contrast, hay and pasture fields, which had not been treated with any of the three pesticides of interest, had lower pesticide concentrations in the OLF samples than the CFP samples. Because the CFPs from these fields originated in upgradient unsampled corn fields, these results suggest that the CFPs were a conduit for pesticides applied in the corn fields and were simply flowing through the hay and pasture fields. Similarly, CFPs in riparian buffers and grass pathways located between the row-cropped fields and the stream tended to have lower concentrations than the upland field $(O L F-F)$ but higher concentrations than the buffer OLF, suggesting a potential for increasing overland flow effectiveness in riparian zones by interrupting CFPs leading to the stream. This study highlights the importance of the land management factors and hydrologic connectivity that cause CFPs to serve different functions (mitigation or enhancement) as runoff is conveyed from agricultural fields to a riparian buffer, and ultimately to an adjacent stream. Further, the results highlight the need for design and maintenance solutions addressing the erosion and sediment control issues that commonly undermine agricultural buffer effectiveness.
\end{abstract}

Keywords. Buffers, Concentrated flow, Contaminant fate and transport, Hydrology, Land management, Pesticides, Overland flow, Water quality.

\footnotetext{
(c) (1) $(-)$ The authors have paid for open access for this article. This cC ${ }_{\text {BY NG ND }}$ work is licensed under a Creative Commons AttributionNonCommercial-NoDerivatives 4.0 International License https://creative commons.org/licenses/by-nc-nd/4.0/

Submitted for review on 23 July 2020 as manuscript number NRES 14221; approved for publication as an Invited Research Article and as part of the Preferential Flow and Piping in Riparian Buffers Collection by the Natural Resources \& Environmental Systems Community of ASABE on 24 February 2021.

Mention of company or trade names is for description only and does not imply endorsement by The Pennsylvania State University and the USDA. All entities are equal opportunity providers and employers.
}

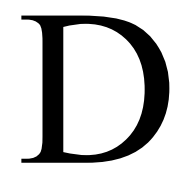
egraded water quality in the Chesapeake Bay and its tributaries has been a major concern in the MidAtlantic region of the eastern U.S. since the 1980s. In upland areas of the bay's watershed, nonpointsource water quality degradation is largely due to runoff from agricultural fields. This degradation has led to a focus by bay restorers on reducing nitrogen and phosphorous concentrations in sedimentation and runoff. However, agricultural pesticides also bind to soil sediments or dissolve in storm water and become mobilized during surface runoff events.

Three agricultural pesticides with widespread usage are atrazine, metolachlor, and imidacloprid. In the U.S., approximately 34,000 metric tons of atrazine was applied in 2007 
(Shelley et al., 2012). With a half-life that can be as long as 16 years, atrazine persists in the environment and poses a long-term risk to human and aquatic health (SalazarLedesma et al., 2018). Metolachlor targets pre- and postemergent weeds and is commonly applied with atrazine to row-crop fields. It has been detected in streams at concentrations that are known to cause negative impacts on ecosystem health, including oysters and rainbow trout (Lipton, 2019; Wan et al., 2006), as well as human health (Hartnett et al., 2013; Li et al., 2018). Imidacloprid, a widely used, broadspectrum neonicotinoid insecticide, appears to either persist in the soil or transport readily through the environment because only a small portion of its application mass has been accounted for in plant uptake (Alford and Krupke, 2017; Sheets, 2010).

After pesticides are applied to crop fields, their fate and transport are governed by the coupling of biogeochemistry and hydrology. The physico-chemical properties of the pesticides govern their partitioning between soil organic carbon and water, movement through the soil profile via leaching, volatilization to the atmosphere, mobility in surface runoff, and degradation by biotic and abiotic factors. The parameters most relevant to understanding the environmental fate, transport, and persistence of atrazine, metolachlor, and imidacloprid include first-order degradation rates (i.e., half-lives), organic carbon partition coefficients $\left(K_{O C}\right)$, aqueous solubility, and vapor pressure (table 1). Pesticides can be transported via surface runoff, infiltration through the soil profile, leaching to groundwater, uptake by crops, and volatilization (fig. 1). The importance of each pathway may vary by pesticide, with surface runoff potentially more important for pesticides applied via spraying than applied directly on seeds.

As Pennsylvania continues to promote adoption of new agricultural best management practices (BMPs) for meeting Chesapeake Bay water quality restoration goals, widespread adoption of riparian buffers is anticipated on farms with streams that traverse or border them. Riparian buffers are composed of vegetation, usually trees, shrubs, and grasses, planted in the riparian zones along streams (Klapproth and
Johnson, 2009; USDA, 2020). Their purpose is to slow the movement of surface runoff and promote interaction of nitrogen, phosphorus, sediment, and other pollutants present in the surface runoff with the vegetation and soil microorganisms. The plants physically trap the sediment and sediment-bound pollutants, effectively removing them from the surface runoff as the water travels through the buffer.

By slowing flow, vegetation in the riparian buffers enhance infiltration into the riparian soil (Lin et al., 2006). This provides filtering of the water and helps detain and trap waterborne pollutants into surface residue and the soil profile. Subsurface lateral flow is also treated in the riparian buffer, with denitrification and the incorporation of soluble fractions of nitrogen and phosphorus into organic matter and plants serving as important processes in the biological treatment of the water (Puckett, 2004). Soluble fractions of pesticides are also likely retained in the riparian buffer's vadose zone as the water moves laterally from the field to the stream (Reungsang et al., 2005). Considered one of the most effective BMPs, riparian buffers have been shown to reduce nutrients and sediment from entering adjacent waterways by as much as 99\% (Liu et al., 2017; Zhang et al., 2010). Although the main focus of riparian buffers as BMPs has been to reduce nutrients and sediments in surface runoff from agricultural fields, agricultural pesticides may also be mitigated by as much as $70 \%$ to $94 \%$ by well-maintained riparian buffers (Reungsang et al., 2005). However, riparian buffer performance over extended time periods is still not well understood, and long-term performance data sets are minimal (Liu et al., 2017). Some data suggest that after approximately a decade, buffers may begin to act as a source of contaminants, such as phosphorus, if the biogeochemical capacity of the buffer is exceeded (Dodd et al., 2018).

Buffers perform best when surface runoff is traveling as sheet flow through the vegetation (Dosskey et al., 2002; Knight et al., 2010; Lyons et al., 2000; Myers et al., 1995; Sheridan et al., 1999), enabling a longer residence time and providing the maximum opportunity for interaction between water and the components of the buffer that provide physico-

Table 1. Physico-chemical properties of pesticides of interest (from CDPR, 2019, except as noted).

\begin{tabular}{|c|c|c|c|c|c|}
\hline Pesticide & $\begin{array}{c}\text { Structure } \\
\text { (from Kim et al., 2019) }\end{array}$ & $\begin{array}{l}\text { Half-Life } \\
\text { in Soil } \\
\text { (days) } \\
\end{array}$ & $\begin{array}{c}\text { Organic Carbon } \\
\text { Partition Coefficient } \\
\left(K_{O C}, \mathrm{~L} \mathrm{~kg}^{-1}\right)\end{array}$ & $\begin{array}{l}\text { Aqueous } \\
\text { Solubility } \\
\left(\mathrm{mg} \mathrm{L}^{-1}\right) \\
\end{array}$ & $\begin{array}{c}\text { Vapor } \\
\text { Pressure } \\
\left(\mathrm{mm} \mathrm{Hg} \text { at } 20^{\circ} \mathrm{C}\right) \\
\end{array}$ \\
\hline Atrazine & & 146 & 155 & 33 & $3 \times 10^{-7}$ \\
\hline Metolachlor & & 114 & 200 & 530 & $1.3 \times 10^{-5}$ \\
\hline Imidacloprid & & 27 to 229 & 132 to 310 & 514 & $1.0 \times 10^{-7}$ \\
\hline
\end{tabular}




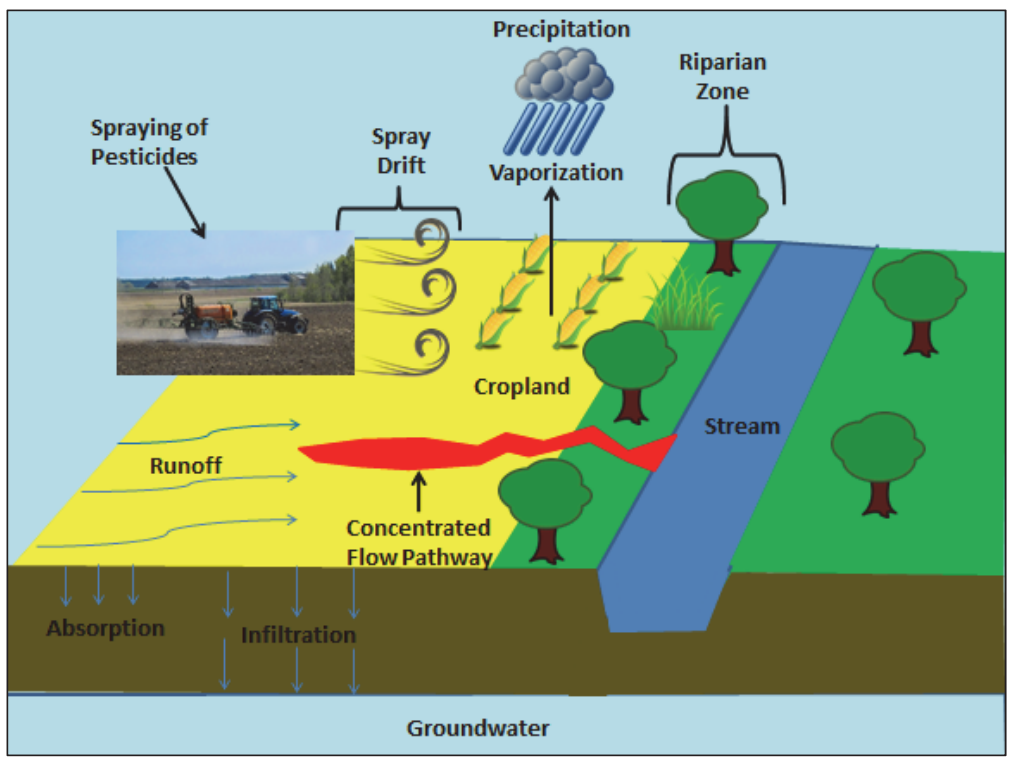

Figure 1. Schematic of pesticide fate and transport after application in an agroecosystem. Relative importance of each transport pathway varies by pesticide type.

chemical and biological treatment. However, buffer integrity is undermined by the presence of concentrated flow pathways (CFPs), which cause "short-circuiting" through the buffers and essentially allow the surface overland flow (OLF) to bypass the buffer and enter the stream untreated (Wallace et al., 2018; Zhang et al., 2010).

CFPs occur naturally when OLF travels distances of $\sim 30$ to $100 \mathrm{~m}$ and begins to converge, forming shallow concentrated flow through erosional rills or other landscape features. Although the formation of many CFPs is driven by surface soil characteristics and local topography, the occurrence of CFPs and associated increases in erosion are exacerbated in agricultural landscapes due to anthropogenic activities, such as plowing and tilling practices, soil compaction from heavy farm machinery, and repetitive livestock movement to and from streams. For example, a study that examined 389 agricultural fields in Illinois found that the fields had an average of five CFPs, with a range from 0 to 17 (Shrestha et al., 2018).

When concentrated flow occurs within a riparian buffer, the effective area that the buffer treats can be substantially reduced. Dosskey et al. (2002) found that the presence of CFPs within a riparian buffer in Nebraska reduced the buffer's ability to treat suspended sediment in surface runoff by as much as $78 \%$. A study in the Chesapeake Bay watershed demonstrated similar findings, with forested buffers treating only $\sim 20 \%$ of the areas contributing runoff to the buffers because of the presence of CFPs (Wallace et al., 2018). Although the occurrence of CFPs in agricultural landscapes has been documented, understanding how their presence affects the effectiveness of riparian buffers at removing pollutants from surface runoff has received limited attention.

Reported herein is a reconnaissance study to improve scientific understanding of the role that CFPs play in the movement of pesticides across agricultural hillslopes via surface runoff. Our research sought to identify the potential role that CFPs can play in altering the transport of pesticides from agricultural fields to nearby streams by examining interactions among land use type (i.e., row-crop, pasture/hay, or riparian buffer), physico-chemical properties of the pesticides, and types of CFP (i.e., topographical, animal-driven, or natural spring). We anticipate that the findings will help inform future modeling and field investigations and will be used to support implementation of field-scale BMPs that are likely to be most effective in reducing pesticide transport to surface water.

\section{Materials ANd Methods}

\section{STUDY SITE}

Soil sampling was performed within a $7.2 \mathrm{~km}^{2}$ subwatershed of the Mahantango Creek watershed, commonly referred to as WE-38 (fig. 2), which drains into the Susquehanna River and then into the Chesapeake Bay. The area is part of a Long-Term Agroecosystem Research (LTAR) site and, as such, our research group has strong relationships with the farmers and landowners, which enables access to fields throughout the watershed. The WE-38 subwatershed is a dominantly agricultural watershed, with about $57 \%$ of the subwatershed in rotational forage crops such as corn, soybeans, and small grains, and $8 \%$ in permanent, minimally managed pasture (Pionke and Glotfelty, 1990; Bryant et al., 2011). The remaining $35 \%$ of the subwatershed, particularly the uppermost edge, is forested. The topography is mainly rolling hillslopes, common in the ridge and valley physiographic region of Pennsylvania. The area also contains many springs and seeps, some of which occur in the crop fields and influence the development of CFPs. Riparian zones in the study watershed are generally unmanaged woody vegetation. The streams located in the study area are classified as warm water fisheries.

A total of nine sampling sites (Hirt et al., 2020) were selected for their representation of common agricultural land uses, with five row-cropped, two hay, and two pasture fields (fig. 2). The dominant soil series for the row-cropped fields were Calvin (loamy-skeletal, mixed, active, mesic Typic 


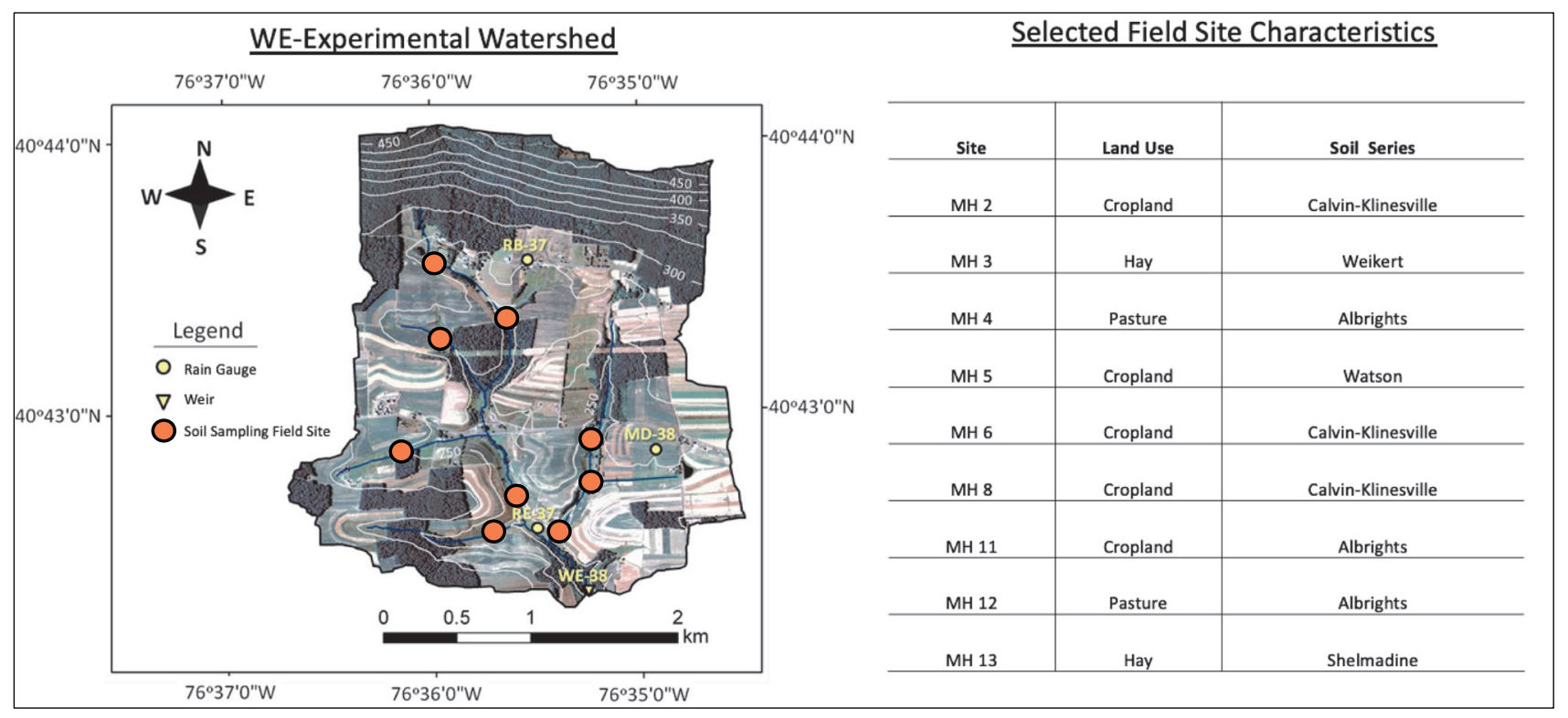

Figure 2. Study site map of the WE-38 experimental watershed (source: Bryant et al., 2011) and characteristics of the nine sampling sites (soils data from USDA, 2019). Site locations are shown on the map without identification numbers to keep landowners anonymous. The MH in the site ID refers to the Mahantango Creek watershed.

Dystrudepts) and Klinesville (loamy-skeletal, mixed, active, mesic Lithic Dystrudepts) with an average slope of $12 \%$. The soil series for the pasture fields was Albrights (fine-loamy, mixed, semiactive, mesic Aquic Fragiudalfs), while the soil series for the hay fields were Weikert (loamy-skeletal, mixed, active, mesic Lithic Dystrudepts) and Shelmadine (fineloamy, mixed, semiactive, mesic Typic Fragiaquults). The pasture fields had an average slope of $14 \%$, while the hay fields had an average slope of $16 \%$. Land management data and pesticide application information were obtained for each of the selected fields and are detailed by Chandler (2019). In brief, all row-cropped fields are managed in corn-soy rotations for forage purposes, and the corn crops receive annual herbicide mixtures of S-metolachlor and atrazine. Additionally, corn seed is typically coated with imidacloprid.

\section{CFP IDENTIFICATION}

The presence and formation of CFPs were documented during site visits in a one-month period from May to June in 2018, which was one of the wettest years on record for this region (NCDC, 2020). Any topographical, subsurfacedriven (e.g., seeps), erosional, or biological features that could have impacted CFP formation were noted. Topographically driven CFPs were identified by noting swales. Usually, these areas had grass strips, which reduced erosion. Additionally, erosional paths were found most often in crop fields and can change from year to year. These paths can be caused by tractor ruts or from loose soil exposed to rainfall.

\section{SoIL SAMPLING}

At each sampling site, multiple soil samples for determining pesticide content were collected within each physical region of the site (fig. 3): CFPs and OLFs in the agriculturally managed portion of the field (denoted CFP-F and OLF-F, respectively), and CFPs and OLFs in the riparian zone (denoted CFP-R and OLF-R, respectively). Sampling was performed on both sides of the stream if the stream went through the site. In these cases, the sample site was subdivided into side A for the left side of the stream and side B for the right side, when facing upstream.

The soil sampling strategy employed for this research resulted in a total of 45 composite samples, with 29 from rowcropped fields and 16 from pasture/hay fields. The 29 rowcropped samples included 17 samples in the fields (nine OLF-F, eight CFP-F) and ten samples collected in the riparian zones of the row-cropped fields (eight OLF-R, two CFP-R). The remaining two row-cropped samples were collected in distinct grass and wetlands areas within the riparian zone (fig. 3). Of the 16 samples collected from pasture/hay fields, eight were classified as OLF-F and eight as CFP-F. None of the pasture/hay fields had riparian buffers that could be sampled.

Soils were sampled to a depth of $2 \mathrm{~cm}$ using handheld soil probes and composited by physical region within each site, i.e., between CFP and OLF samples in each land use type and across sites or sides of the stream. The soil probes were cleaned with $95 \%$ ethanol between soil composites to minimize cross-contamination. Sterile nitrile gloves were also used during sampling and were changed each time the soil probes were sanitized to reduce cross-contamination. Each composite sample consisted of 15 to 20 core samples ( 0 to $2 \mathrm{~cm}$ depth) sealed into plastic Ziploc bags, which were properly labeled and stored in backpacks with ice packs. During transport back to campus, the bags were kept on ice inside a cooler and, upon arrival at Penn State University, placed in a Thermax freezer at $-17^{\circ} \mathrm{C}$ until analysis preparation began.

\section{SAMPLE ANALYSIS}

The samples were lyophilized using a Virtis 35XL freeze dryer (SP Scientific, Gardiner, N.Y.) to less than $1 \%$ moisture over a 3-day drying cycle. The dried samples were milled, passed through a No. 10 sieve, and then bagged, 

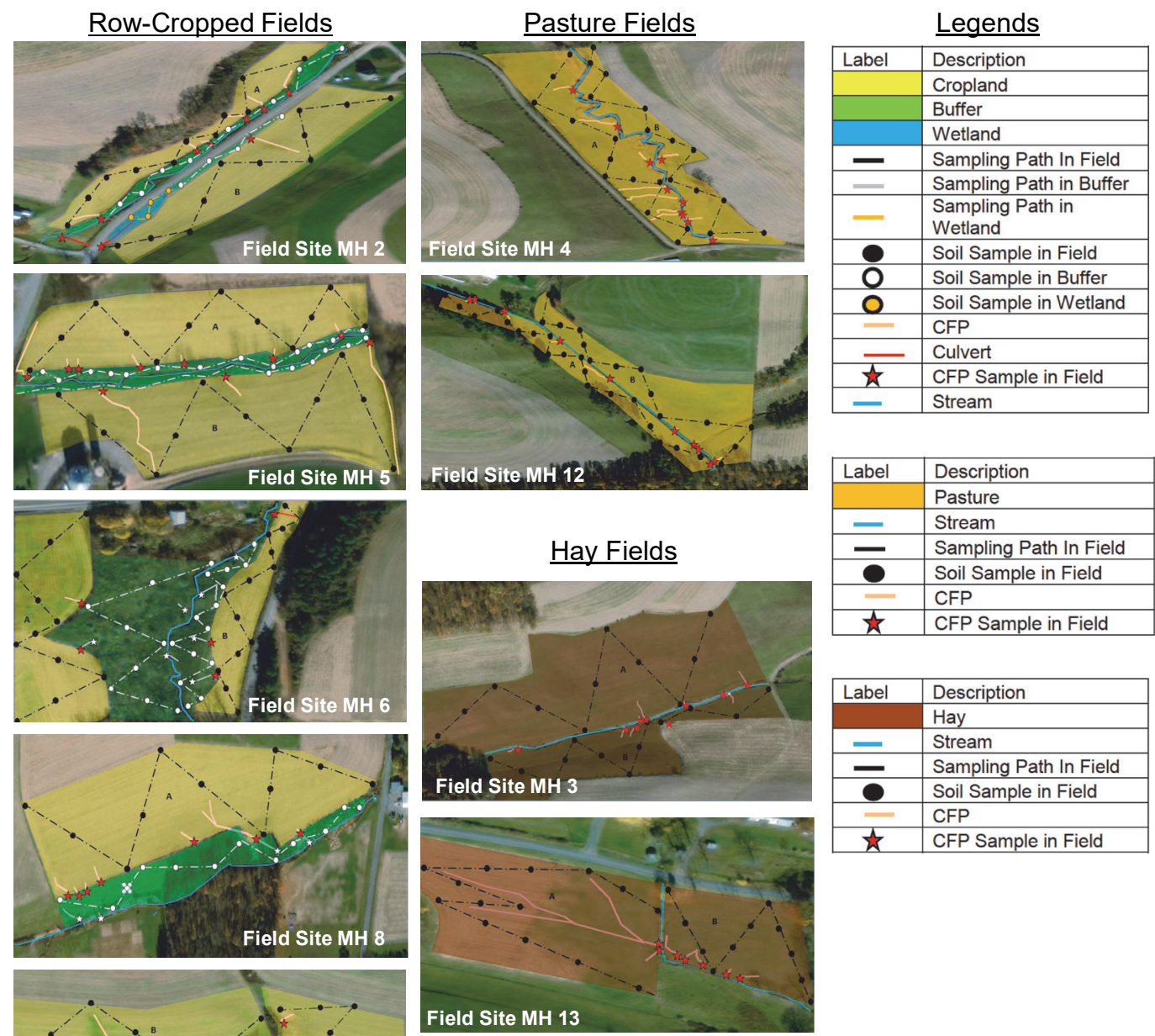

\begin{tabular}{|c|l|}
\hline Label & Description \\
\hline & Hay \\
\hline- & Stream \\
\hline- & Sampling Path In Field \\
\hline- & Soil Sample in Field \\
\hline & CFP \\
\hline \multicolumn{1}{|}{} & CFP Sample in Field \\
\hline
\end{tabular}

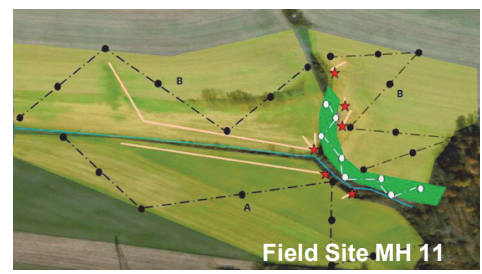

Figure 3. Schematic of sampling strategy in each field of interest (cropland, pasture, and hay) and associated buffer zones (CFP = concentrated flow pathway). Sides of the field are labeled $A$ and $B$ when a stream runs through the field. Side $A$ is on the left when facing upstream, and side $B$ is on the right. Aerial images are from Google Maps in 2019 (https:/www.google.com/maps).

labeled, and refrozen until they could be processed with QuEChERS (quick, easy, cheap, effective, rugged, safe) extraction. The QuEChERS extraction process involves combining $7.5 \mathrm{~g}$ of soil, $1.5 \mathrm{~g}$ of anhydrous sodium acetate, $6 \mathrm{~g}$ of anhydrous magnesium sulfate, and $10 \mathrm{~mL}$ of $1 \%$ acetic acid in acetonitrile in a $50 \mathrm{~mL}$ centrifuge tube, which is then vortexed for $30 \mathrm{~s}$ and centrifuged at $3000 \mathrm{rpm}$ for $5 \mathrm{~min}$ at $20^{\circ} \mathrm{C}$. Ten $\mathrm{mL}$ of supernatant is then added to a $15 \mathrm{~mL}$ centrifuge tube containing $1.2 \mathrm{~g}$ of anhydrous magnesium sulfate and $400 \mathrm{mg}$ of primary-secondary amine (PSA) resin, and vortexed for $30 \mathrm{~s}$. The mixture is centrifuged at $3000 \mathrm{rpm}$ for $5 \mathrm{~min}$ at $20^{\circ} \mathrm{C}$. Finally, $200 \mu \mathrm{L}$ of supernatant is transferred to a $1 \mathrm{~mL}$ vial containing $300 \mu \mathrm{L}$ of acetonitrile, and $500 \mu \mathrm{L}$ of $8 \mathrm{mM}$ ammonium formate buffer.

The three pesticides in the soil samples were analyzed and quantified using a high-resolution accurate mass (HRAM) Q Exactive mass spectrometer (Thermo-Fisher Scientific, Bremen, Germany), interfaced with an ICS-5000+ chromatography system (Thermo-Fisher Dionex, Sunnyvale, Calif.) via a heated electrospray injection (HESI) source. Ten $\mu \mathrm{L}$ of processed sample extract was injected onto a $2.1 \times 100 \mathrm{~mm}$, $3 \mu \mathrm{m}$ Hypersil Gold aQ column (Thermo-Fisher Scientific, San Jose, Calif.) and eluted using $0.1 \%$ formic acid and $4 \mathrm{mM}$ ammonium formate in water (A) and methanol (B) under the following linear gradient: $88 \% \mathrm{~A}$ and $12 \% \mathrm{~B}$ at $0 \mathrm{~min}$, $100 \%$ B at 9 min with a 2 min hold, followed by a 3 min equilibration at $88 \% \mathrm{~A}$ and $12 \% \mathrm{~B}$. The flow rate during elution was $0.3 \mathrm{~mL} \mathrm{~min}{ }^{-1}$. The mass range was scanned from 80 to $1100 \mathrm{~m} / \mathrm{z}$ with a resolution of 70,000 and operated in datadependent MS2 mode for all three pesticides (atrazine, metolachlor, and imidacloprid). The ddMS2 mode used a resolution of 35,000 and normalized collision energies of 20, 40, and 60 electron volts. The percent recoveries from solution for the three pesticides were determined using the standard addition method and were found to be greater than $90 \%$. The calibration range for each pesticide was 0.1 to $100 \mu \mathrm{g} \mathrm{L}^{-1}$. The instrument limit of detection (LOD) was $0.01 \mu \mathrm{g} \mathrm{L}^{-1}$, and the limit of quantification (LOQ), determined using signal- 
to-noise ratios of 3 and 10 over background, was $0.1 \mu \mathrm{g} \mathrm{L}^{-1}$. This translated to a dry soil LOD of $0.02 \mu \mathrm{g} \mathrm{kg}^{-1}$ and LOQ of $0.2 \mu \mathrm{g} \mathrm{kg}^{-1}$ for each pesticide.

\section{Data ANALYSis}

Pesticide concentrations for the composited samples within each field were normalized by the concentration of the OLF-F composite sample at that field to determine whether concentrations increased or decreased along the flow path from the field to the stream. When unnormalized concentrations were below the LOQ, a value equal to LOQ/2 $\left(0.1 \mu \mathrm{g} \mathrm{kg}^{-1}\right)$ was used in calculating averages and percent differences.

Pesticide concentrations were grouped together in two manners to compare results across the study watershed. First, pesticide concentrations were grouped based on collection from OLF or CFP. Second, samples were grouped together based on land use: row crop versus pasture and hay field. None of the pesticides of interest were directly applied to the pasture and hay fields, thereby allowing data to be compared between areas where pesticides were directly applied (corn fields) to areas where the pesticides were not directly applied. The mean pesticide concentrations in each group of samples were then compared by conducting a two-sample t-test using Minitab (2019). Equal variance was not assumed during the analyses, and a confidence interval of $95 \%$ was used.

\section{RESULTS AND DISCUSSION}

Overall, approximately $48 \%$ of the composited samples had at least one pesticide concentration below the LOQ (table 2). Imidacloprid was generally present at the highest concentrations, with concentrations ranging from below the LOD to as high as $2085 \mu \mathrm{g} \mathrm{kg}^{-1}$. Atrazine concentrations averaged $1.86 \mu \mathrm{g} \mathrm{kg}^{-1}$ in row-cropped fields compared to $0.40 \mu \mathrm{g} \mathrm{kg}^{-1}$ in pasture/hay fields. Metolachlor was present in the rowcropped fields at an average concentration of $22.5 \mu \mathrm{g} \mathrm{kg}^{-1}$, which was approximately 46 times higher than the average concentration of $0.49 \mu \mathrm{g} \mathrm{kg}^{-1}$ observed in the pasture/hay fields. Imidacloprid concentrations were 35 times higher in the row-cropped fields $\left(\sim 261 \mu \mathrm{g} \mathrm{kg}^{-1}\right)$ compared to the pasture/hay fields $\left(\sim 7.5 \mu \mathrm{g} \mathrm{kg}^{-1}\right)$. In general, concentrations of atrazine and metolachlor were 2 to 3 times higher in the OLF versus the CFPs of the row-cropped fields. However, in the pasture/hay fields, all three pesticides were present at higher concentrations in the CFPs than the OLF (table 2).

A two-sample t-test of each pesticide concentration within each land use (table 3 ) revealed no statistical difference at $\mathrm{p}<0.05$ other than for atrazine in row-cropped fields $(\mathrm{p}<0.012)$. Because the concentrations of samples were statistically similar when grouped by land use type and flow pathway type, an investigation of site-specific trends and originations of the CFPs was conducted.

\section{PATTERnS ObSERVEd IN ROW-CrOpPED FiELdS}

Atrazine and metolachlor were applied to the rowcropped corn fields with hydraulic sprayers such that these pesticides covered the entire field, including both OLF and CFP areas. In contrast, imidacloprid is a neonicotinoid
Table 2. Pesticide concentrations in each region of each sampled site.

\begin{tabular}{|c|c|c|c|c|c|}
\hline \multirow[b]{2}{*}{ Land Use } & \multirow[b]{2}{*}{ Field $^{[\mathrm{a}]}$} & \multirow{2}{*}{$\begin{array}{l}\text { Sample } \\
\text { Type }^{[\mathrm{b}]}\end{array}$} & \multicolumn{3}{|c|}{ Concentration $\left(\mu \mathrm{g} \mathrm{kg}^{-1}\right)^{[\mathrm{c}]}$} \\
\hline & & & Atrazine & Metolachlor & Imidacloprid \\
\hline \multirow[t]{29}{*}{ Row crop } & MH 2 A & OLF-F & 2.43 & 85.22 & 150.28 \\
\hline & & CFP-F & 3.37 & 11.65 & $<\mathrm{LOQ}$ \\
\hline & & OLF-R & 0.66 & 1.11 & 83.27 \\
\hline & & CFP-R & 1.29 & 1.48 & $<\mathrm{LOQ}$ \\
\hline & & Grass & 1.04 & 7.99 & 108.48 \\
\hline & MH 2 B & OLF-F & 2.54 & 3.37 & 299.65 \\
\hline & & CFP-F & 0.37 & 0.40 & 28.96 \\
\hline & & OLF-R & 0.34 & 0.40 & $<\mathrm{LOQ}$ \\
\hline & & Wetland & 2.78 & 3.42 & 78.73 \\
\hline & MH 5 A & OLF-F & 2.36 & 127.82 & 83.81 \\
\hline & & CFP-F & 1.86 & 33.50 & 21.01 \\
\hline & & OLF-R & 1.23 & 4.75 & $<\mathrm{LOQ}$ \\
\hline & MH 5 B & OLF-F & 2.11 & 50.95 & 231.71 \\
\hline & & CFP-F & 1.88 & 53.03 & 61.18 \\
\hline & & OLF-R & 0.60 & 3.03 & 15.23 \\
\hline & $\mathrm{MH} 6 \mathrm{~A}$ & OLF-F & 1.96 & 3.81 & 36.25 \\
\hline & & OLF-R & 0.42 & 0.37 & $<\mathrm{LOQ}$ \\
\hline & MH 6 B & OLF-F & 3.09 & 4.17 & $<\mathrm{LOQ}$ \\
\hline & & CFP-F & 0.55 & 0.66 & $<\mathrm{LOQ}$ \\
\hline & & OLF-R & 0.27 & $<\mathrm{LOQ}$ & $<\mathrm{LOQ}$ \\
\hline & MH 8 & OLF-F & 1.07 & 1.93 & 83.81 \\
\hline & & CFP-F & 0.98 & 1.31 & 2085.26 \\
\hline & & OLF-R & 0.60 & 0.81 & 6.03 \\
\hline & & CFP-R & 0.56 & 0.67 & 40.20 \\
\hline & $\mathrm{MH} 11 \mathrm{~A}$ & OLF-F & 2.01 & 1.69 & 587.99 \\
\hline & & CFP-F & 1.34 & 1.03 & 328.91 \\
\hline & MH $11 \mathrm{~B}$ & OLF-F & 1.84 & 1.20 & 230.89 \\
\hline & & CFP-F & 1.87 & 1.03 & 209.16 \\
\hline & & OLF-R & 1.85 & 1.98 & 12.43 \\
\hline \multirow[t]{8}{*}{ Pasture } & $\mathrm{MH} 4 \mathrm{~A}$ & OLF-F & $<\mathrm{LOQ}$ & $<\mathrm{LOQ}$ & $<\mathrm{LOD}$ \\
\hline & & CFP-F & $<\mathrm{LOQ}$ & $<\mathrm{LOQ}$ & $<$ LOD \\
\hline & MH 4 B & OLF-F & 0.24 & 0.28 & $<$ LOD \\
\hline & & CFP-F & 0.30 & $<\mathrm{LOQ}$ & $<\mathrm{LOD}$ \\
\hline & $\mathrm{MH} 12 \mathrm{~A}$ & OLF-F & 0.38 & $<\mathrm{LOQ}$ & 14.85 \\
\hline & & CFP-F & 0.26 & $<\mathrm{LOQ}$ & $<$ LOQ \\
\hline & MH 12 B & OLF-F & 0.36 & $<\mathrm{LOQ}$ & $<\mathrm{LOQ}$ \\
\hline & & CFP-F & 0.23 & $<\mathrm{LOQ}$ & 44.72 \\
\hline \multirow[t]{8}{*}{ Hay } & $\mathrm{MH} 3 \mathrm{~A}$ & OLF-F & $<\mathrm{LOQ}$ & $<\mathrm{LOQ}$ & $<$ LOQ \\
\hline & & CFP-F & 0.92 & 0.85 & 223.77 \\
\hline & MH 3 B & OLF-F & $<\mathrm{LOQ}$ & $<\mathrm{LOQ}$ & $<\mathrm{LOQ}$ \\
\hline & & CFP-F & 0.44 & 0.69 & 368.99 \\
\hline & $\mathrm{MH} 13 \mathrm{~A}$ & OLF-F & 1.35 & 3.27 & $<\mathrm{LOD}$ \\
\hline & & CFP-F & 1.28 & 1.63 & $<\mathrm{LOD}$ \\
\hline & MH 13 B & OLF-F & $<\mathrm{LOQ}$ & $<\mathrm{LOQ}$ & $<$ LOD \\
\hline & & CFP-F & $<\mathrm{LOQ}$ & $<\mathrm{LOQ}$ & $<\mathrm{LOD}$ \\
\hline
\end{tabular}

[a] A and $\mathrm{B}$ designate the left (A) and right (B) sides of the stream when looking upstream.

[b] OLF = overland flow samples collected in the agricultural field (F) and riparian buffer $(\mathrm{R})$, and CFP = concentrated flow pathway samples collected in the field $(\mathrm{F})$ and riparian buffer $(\mathrm{R})$.

[c] $\mathrm{LOD}=$ limit of detection $\left(0.02 \mu \mathrm{g} \mathrm{kg}^{-1}\right)$, and LOQ $=$ limit of quantification $\left(0.2 \mu \mathrm{g} \mathrm{kg}^{-1}\right)$.

Table 3. Two-sample t-test comparison of pesticide concentrations in overland flow (OLF) versus concentrated flow pathways (CFP) across all row crop fields and all pasture/hay fields.

\begin{tabular}{lcccccc}
\hline & & \multicolumn{2}{c}{ Standard Deviation } & & \multicolumn{2}{c}{ Mean } \\
\cline { 3 - 4 } \cline { 6 - 7 } & p-Value & OLF & CFP & & OLF & CFP \\
\hline Row crop & & & & & & \\
Atrazine & 0.012 & 0.563 & 0.934 & & 2.126 & 1.381 \\
Metolachlor & 0.207 & 40.7 & 14.5 & & 22.1 & 6.5 \\
Imidacloprid & 0.892 & 235.0 & 254.0 & & 223.0 & 511.0 \\
\hline Pasture/hay & & & & & & \\
Atrazine & 0.226 & 0.451 & 0.557 & & 0.303 & 0.609 \\
Metolachlor & 0.685 & 1.14 & 0.75 & & 0.46 & 0.65 \\
Imidacloprid & 0.161 & 5.25 & 128.0 & & 1.86 & 64.0 \\
\hline
\end{tabular}


pesticide that is coated onto the seeds. Therefore, imidacloprid would have been introduced predominately into OLF areas. All fields had crop residue from the previous year and were typically no-till, with the exception of field site MH 6. The CFPs observed in the corn fields were typically erosional and were created by repeated tractor use and exposure of vulnerable soil to rainfall.

\section{Atrazine and Metolachlor}

Atrazine concentrations within the corn fields ranged from 0.27 to $3.37 \mu \mathrm{g} \mathrm{kg}^{-1}$, with $100 \%$ of the samples having concentrations above the LOQ (table 2). Metolachlor concentrations found within row-cropped fields ranged from below the LOQ (one field location) to $\sim 128 \mu \mathrm{g} \mathrm{kg}^{-1}$ (table 2). For both metolachlor and atrazine, OLF-F soil concentrations were consistently higher than CFP-F soil concentrations (fig. 4). Surface runoff via sheet flow carries less sediment than concentrated flow and has been observed in another study to cause atrazine to remain on the land rather than be mobilized by surface runoff (Shen et al., 2018). However, when concentrated flow occurs, sediment-bound atrazine and metolachlor likely become mobilized from within the pathways, resulting in the lower concentrations in the soil within the CFPs compared to the OLF areas of the field.

When exceptions to this trend were observed, they could be explained by the presence of culverts that brought runoff

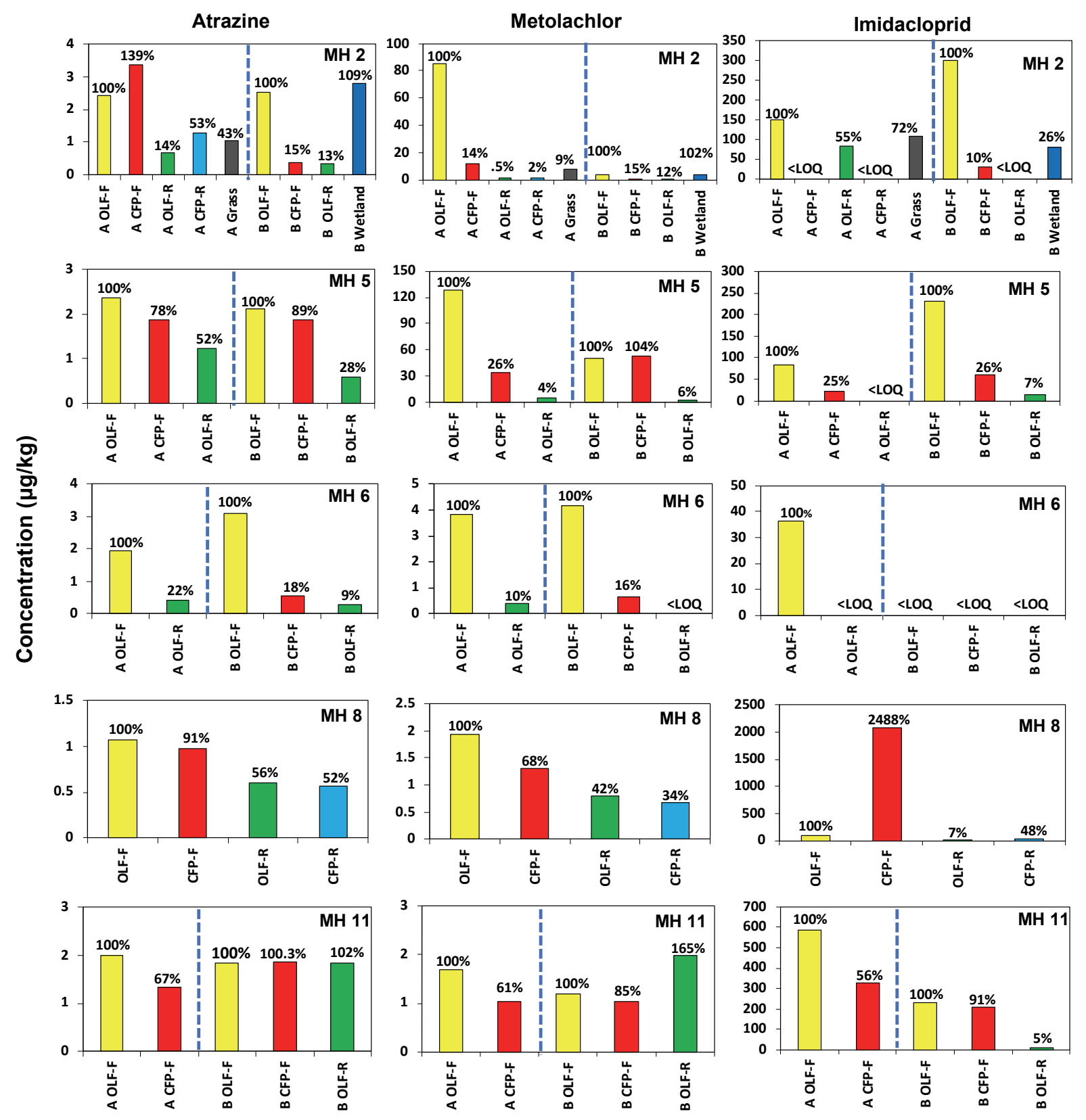

Figure 4. Bar charts of row-cropped field and associated riparian buffer pesticide concentrations as a percentage after normalization by the OLFF sample from each stream side of each sample: OLF = overland flow samples collected in the agricultural field (F) and riparian buffer (R), CFP = concentrated flow pathway samples collected in the field $(\mathrm{F})$ and riparian buffer $(\mathrm{R})$, and LOQ = limit of quantification $\left(0.2 \mu \mathrm{g} \mathrm{kg} \mathrm{g}^{-1}\right)$. Blue dashed lines represent the stream for field sites that had streams running through them such that the results are divided into side $A$ and side $B$ of the stream (left and right, respectively). Note that the $y$-axis is different for most of the graphs. 
from field side $\mathrm{B}$ to side $\mathrm{A}$, resulting in elevated concentrations in atrazine in CFP-F as compared to OLF-F for side A (MH 2; fig. 4). Additionally, the CFPs that formed from upgradient seeps rather than from topography within the field tended to have elevated concentrations of atrazine and metolachlor as compared to other fields (e.g., MH 11; fig. 4). In these cases, pesticides from the upgradient, unsampled, row-cropped fields were likely flushed from the upgradient fields via the CFPs. Thus, it is not surprising that the atrazine and metolachlor concentrations in those seep-driven CFPs passing through the sampled row-cropped fields were similar to the atrazine and metolachlor levels of the OLF areas within the sampled row-cropped fields.

\section{Imidacloprid}

The imidacloprid concentrations found within the corn fields ranged from below the LOQ to $2085 \mu \mathrm{g} \mathrm{kg}^{-1}$, with approximately one-third of the samples below the LOQ. Imidacloprid concentrations were typically greater in OLF-F samples compared to the CFP-F by as much as $91 \%$. There was one exception at MH 8 (table 2; fig. 4) in which an imidacloprid concentration in the CFP was several orders of magnitude higher than the concentrations of the other samples at the field. The CFPs at MH 8 were dominantly driven by seeps. Because imidacloprid has the highest aqueous solubility and a relatively low organic carbon partition coefficient (table 1), it is expected that it was transported from upgradient, unsampled fields that had likely been planted with neonicotinoid-coated seeds.

\section{PATTERnS OBSERVED IN RiPARIAN BUfFERS Atrazine and Metolachlor}

For the five fields that contained riparian buffers (MH 2, $5,6,8$, and 11), atrazine concentrations were lower in the OLF-R samples than the upgradient OLF-F samples, with concentrations reduced by as much as $91 \%$ in the buffer compared to the field. Of the fields with buffer zones, two of them had CFPs that originated in the row-crop field and bypassed the buffers (MH 2 and MH 8; examples in fig. 4). At MH 2, the concentrations in the CFP-R, grass (side A), and wetland (side B) samples were greater than in the OLF-R samples. These observations suggest mobility of the surfaceapplied pesticides through runoff and erosion from the rowcrop field to CFPs that route to the wetland and stream. However, it also provides evidence that CFPs compromise the integrity of buffers and make them less effective in mitigating pesticide transport.

\section{Imidacloprid}

Imidacloprid concentrations were generally low in the riparian buffer samples, with a maximum concentration of $209 \mu \mathrm{g} \mathrm{kg}^{-1}$ (table 2). CFP-R and OLF-R concentrations were generally at least $52 \%$ lower and $45 \%$ to $95 \%$ lower, respectively, than in the upgradient OLF-F areas. The grass and wetland sample concentrations for field $\mathrm{MH} 2$ were $28 \%$ and $74 \%$ lower, respectively, than the upgradient OLF-F concentration. The decreased imidacloprid concentrations in the riparian zone, as compared to the concentrations in the fields where the imidacloprid-coated corn seeds were planted, are likely due to subsurface flow rather than surface runoff being the dominant transport pathway for imidacloprid (Frame et al., 2021), as compared to atrazine and metolachlor. It is unlikely that imidacloprid was bound to sediment that was transported during surface runoff, as the mobilized imidacloprid originated from the planted seeds below the soil surface. Therefore, it would not be expected to be deposited with sediment trapped by the buffer vegetation, and a riparian buffer designed to treat surface flow may not be as effective for imidacloprid as for atrazine and metolachlor.

\section{Patterns Observed in Pasture Fields}

The pasture (MH 4 and $\mathrm{MH}$ 12) fields were not treated with any pesticides; thus, the only source of the pesticides observed in the pasture fields was the upgradient corn fields. The CFPs present in the pasture fields typically originated in the upgradient corn fields, and the flow dispersed into sheet flow when entering the pasture field. The CFPs observed to start in the pasture fields were either biological (repeated cattle movement) or groundwater-driven seeps. The results for the samples collected in the pasture fields were affected by a rainfall event that occurred between sampling dates. Samples from all other individual fields were collected on the same day; therefore, interpretation of results from other fields was not confounded by rainfall events.

\section{Atrazine}

Atrazine concentrations observed within the pasture fields ranged from below the LOQ to approximately $0.4 \mu \mathrm{g} \mathrm{kg}^{-1}$. These concentrations were approximately an order of magnitude lower than the concentrations observed in the row-cropped fields (table 2). The results from the two pasture fields varied, with no clear pattern emerging (fig. 5). At MH 4 (fig. 3), the concentrations of atrazine were less than the LOQ on side A of the stream. On side B, atrazine was present at a higher concentration in the CFP composite sample compared to the composite sample from the remainder of the field site (i.e., the areas that likely experienced sheet flow) by approximately $30 \%$. The low concentrations on side A were likely due to no atrazine having been applied in the field and no immediately upgradient sources of atrazine that entered the CFP. On side B, atrazine was likely transported by surface runoff from the immediately upgradient row-cropped field to which atrazine is known to have been applied. The night prior to sampling, a $5 \mathrm{~cm}$ rainfall event occurred, which likely mobilized atrazine and resulted in detectable levels in the OLF-F and CFP-F samples despite no atrazine being applied directly to the pasture. On side B, the CFPs were characterized as old stream channels and compaction trails from cattle and driven by erosional processes that mobilized upgradient sources of sediment-bound pesticides that then deposited in the CFPs as flow moved toward the stream. At MH 12 (fig. 3), atrazine concentrations were higher in OLF-F samples than in CFP samples; however, they were still lower than the atrazine concentrations observed in the row-cropped fields. The higher concentrations of atrazine at MH 12 in the OLF areas could be due to more frequent activation of sheet flow pathways, potentially elevating the atrazine concentrations in the portions of the field that received upgradient runoff as sheet flow, or due to 


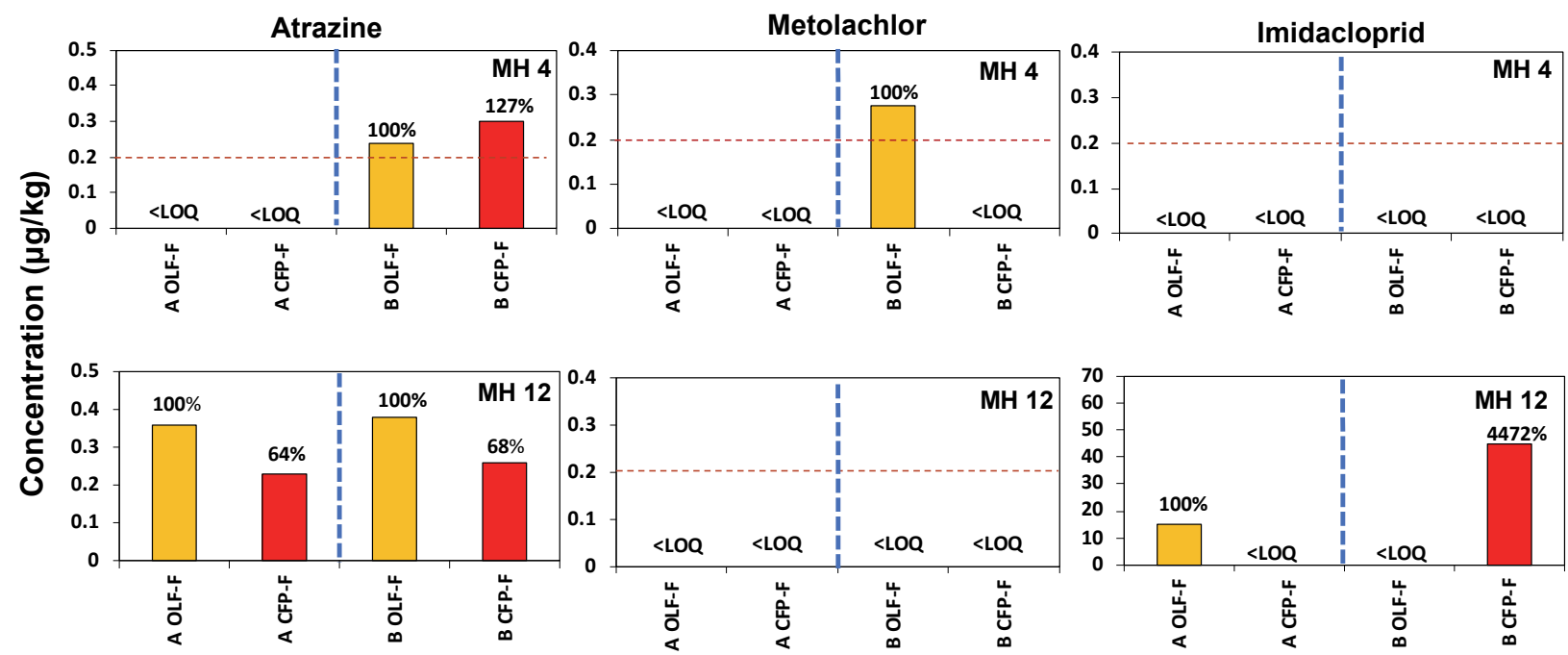

Figure 5. Pasture field pesticide concentrations, as a percentage after normalization by the OLF-F sample from each stream side of each sample: OLF = overland flow samples collected in the agricultural field $(F)$ and riparian buffer $(R), C F P=$ concentrated flow pathway samples collected in the field (F) and riparian buffer $(R)$, and $L O Q=$ limit of quantification $\left(0.2 \mu \mathrm{g} \mathrm{kg}^{-1}\right)$. Blue dashed lines represent the stream for field sites that had streams running through them. For those sites, the results are divided into side A and side B of the stream (left and right, respectively). When applicable, the red dashed line represents the LOQ. Note that the $y$-axis is different for most of the graphs.
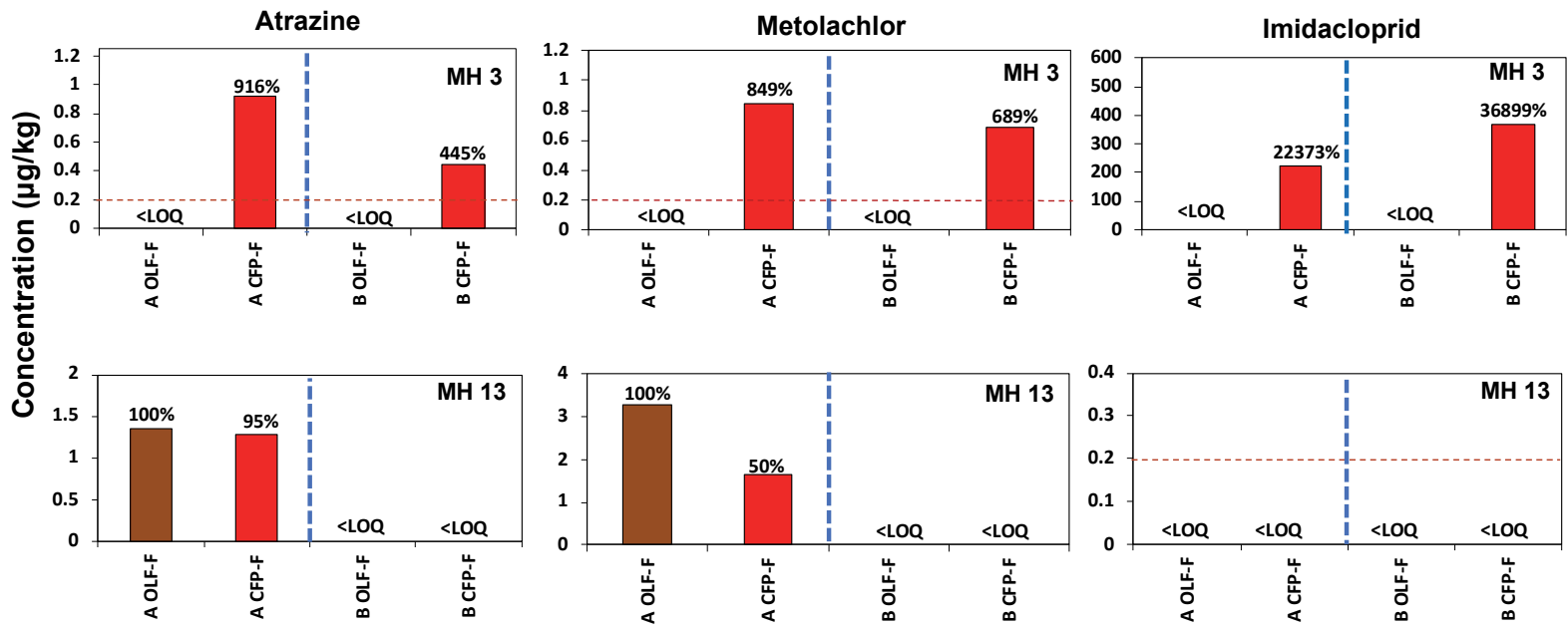

Figure 6. Bar charts of pesticide concentrations from hay field samples: OLF = overland flow samples collected in the agricultural field (F) and riparian buffer $(R), C F P=$ concentrated flow pathway samples collected in the field $(F)$ and riparian buffer $(R)$, and $L O Q=$ limit of quantification $\left(0.2 \mu \mathrm{g} \mathrm{kg}^{-1}\right)$. Blue dotted lines represent the stream for field sites that had streams running through them. For those fields, the results are divided into side $A$ and side $B$ of the stream (left and right, respectively). When applicable, the red dashed line represents the LOQ. Note that the $y$-axis is different for most of the graphs.

erosional processes occurring within the CFPs that continually remove atrazine in subsequent storm events after being deposited from upgradient fields from previous events.

\section{Metolachlor}

Unlike atrazine, nearly all metolachlor concentrations were below the LOQ in samples collected from the pasture fields. The only sample from the pasture fields that had a quantifiable level of metolachlor was the composite sample collected from OLF areas of MH 4 A (fig. 6). This was likely due to runoff from the immediately upgradient row-cropped field, which may have received a recent application of metolachlor prior to sampling. This is consistent with the presence of atrazine at $\mathrm{MH} 4 \mathrm{~A}$. The lower detection of metolachlor could be due to a higher sorption coefficient (table 1), which may have resulted in lower mobility of metolachlor from the upgradient field relative to atrazine.

\section{Imidacloprid}

Imidacloprid was only present at quantifiable concentrations in two samples collected in the pasture fields: one of the composite samples collected in the OLF areas of MH $12 \mathrm{~A}$, and the CFP samples of MH $12 \mathrm{~B}$. The imidacloprid found at MH 12 likely came from adjacent croplands that had been planted with imidacloprid-coated seeds. The lack of detection of imidacloprid at MH 4 was likely due to no nearby source, as there were no adjacent cropland fields and no imidacloprid had been applied directly on that field site. Overall, these observations of where imidacloprid was found and where it was absent are consistent with where it 
was applied and where flow was observed to be occurring from a hydrologic connection between the receiving pasture field and upgradient fields that served as imidacloprid sources. Because imidacloprid is the most mobile of the three pesticides (table 1), it is likely easily transported during rainfall events that induce subsurface lateral flow.

\section{PatTerns ObSeRVEd in Hay FieldS}

The hay fields (MH 3 and MH 13) were not treated with any pesticides; thus, similar to the pasture fields, the only sources of the pesticides observed in the hay fields were transported from upgradient corn fields. The topographical features were similar, with CFPs starting in an upgradient, unsampled crop field and dispersing in several directions when entering the hay field (fig. 3). This dispersal is due to the transition of vegetation that occurs on the edge of the fields and by other biological factors, such as rodent trails, observed at the hay field sites. These rodent trails cause small CFPs to form. It was observed that these dispersed CFPs converged again downgradient to form the CFPs located next to the streambank.

\section{Atrazine and Metolachlor}

Atrazine was found in the hay fields at concentrations ranging from below the LOQ to $1.35 \mu \mathrm{g} \mathrm{kg}^{-1}$, while metolachlor was found at concentrations ranging from below the LOQ to $3.27 \mu \mathrm{g} \mathrm{kg}^{-1}$. Half of the samples had concentrations of atrazine and metolachlor below the LOQ, limiting the identification of patterns along the flow pathways. At site $\mathrm{MH}$ 3, which was downgradient of corn fields (fig. 3), the atrazine and metolachlor concentrations in the CFP-F were higher than in those in OLF-F (fig. 6). This was likely due to transport through the CFPs that started in the upgradient corn fields and then dispersed upon entering the hay fields. It was observed that these dispersed CFPs converged again downgradient, such that they formed CFPs again adjacent to the streambank, thereby resulting in elevated concentrations of atrazine in the CFPs. At field MH 13, no quantifiable concentrations of atrazine and metolachlor were found on side $\mathrm{B}$ (table 2). However, side A was located adjacent to a corn field (fig. 3), and atrazine concentrations were found at concentrations of $\sim 1.3 \mu \mathrm{g} \mathrm{kg}^{-1}$. The elevated presence of atrazine at MH 13 A could have been due to spray drift occurring when the pesticide was applied to the corn field. It is also possible that atrazine was applied directly to this area to kill the grass and expand the crop field. The concentrations were similar in the OLF-F and CFP-F samples collected from this field, with concentrations differing by less than a factor of 2 (table 2), suggesting that a mechanism other than flow was responsible for the presence of atrazine and metolachlor at MH 13.

\section{Imidacloprid}

One of the two hay fields ( $\mathrm{MH} 3$ ) had quantifiable concentrations of imidacloprid (table 2). This field was bordered by cropland that appeared to contribute to the presence of atrazine and metolachlor in the CFP samples collected from this site. Therefore, it is consistent with the atrazine and metolachlor observations for imidacloprid to also be present in those samples above the LOQ. It should be noted that the imidacloprid concentrations found in the CFPs at field MH 3 were comparable to some from the crop fields that were sampled (table 2), with concentrations of 200 to $370 \mu \mathrm{g} \mathrm{kg}^{-1}$. Imidacloprid was not present at quantifiable concentrations in the samples collected from the remainder of the field (OLFF samples), and atrazine and metolachlor were also present in the OLF-F samples below the LOQ.

\section{SUMMARY OF TRENDS ACROSS STUDY WATERSHED}

The concentrations of each pesticide varied across the watershed, largely driven by differences in land use (table 2). Samples collected in row-cropped fields typically had higher concentrations of pesticides than samples from hay and pasture fields. This was likely due to application of the pesticides, either from spraying or seed planting, directly within the fields. Row-cropped fields generally had the highest pesticide concentrations in the OLF areas, with concentrations continuing to decrease along the CFPs and through the buffers prior to entering the adjacent streams (fig. 4). When riparian zones were present between the corn fields and the stream, the non-wetland riparian zone concentrations (OLF-R, CFP-R, grass) were generally lower than the concentrations in the field (OLF-F samples). The exceptions to this general pattern were the detection of atrazine in the MH 2 A wetland, and the detection of imidacloprid in the MH 8 CFP-F, which was created by groundwater seeps that appear to enhance the transport of imidacloprid.

Pesticide transport patterns in hay and pasture fields were similar to those for riparian zones. There was no direct application of pesticides to these fields. Thus, the pesticides found at these fields were likely due to transport via groundwater seeps (into CFP-F samples) or surface runoff via OLF and CFP from upgradient fields that had received pesticide applications. Additionally, rainfall events and groundwater recharge prior to the date of sampling may have impacted pesticide concentrations by enhancing transport from upgradient fields or washing out residues from the soils where pesticides had previously been deposited.

The imidacloprid concentrations in this study can be fatal to macroinvertebrates, including earthworms (Eisenia andrei), collembola (Enchytraeus crypticus), orbatida ("moss mites"; Oppia nitensi), and isopods (Porcellio scaber) (de Lima e Silva et al., 2017). The observed soil concentrations of atrazine and metolachlor were similar to those reported in a field study conducted in Connecticut in which soil samples were collected between two and fifteen months after application (Pignatello and Huang, 1991). The ranges of atrazine and metolachlor in that study were 57.6 to $236 \mu \mathrm{g} \mathrm{kg}^{-1}$ dry soil and 37.2 to $510 \mu \mathrm{g} \mathrm{kg}^{-1}$ dry soil, respectively. Although the concentrations in the current study were generally lower than those values, especially for atrazine, the trends are consistent, with concentrations of metolachlor higher in both the current study and the Pignatello and Huang (1991) study.

\section{Conclusions}

This research sought to understand field-scale transport of atrazine, metolachlor, and imidacloprid from application in the field to a nearby stream and the potential role of CFPs 
in bypassing mitigation by downgradient fields or riparian buffers. Statistically, flow pathways (OLFs and CFPs) did not clearly impact pesticide levels by land use type. However, by evaluating the types of CFPs present at each sampling site, in addition to site-specific characteristics, the following trends in the transport of pesticides from field to stream were elucidated:

- In crop fields, pesticide concentrations were typically higher in OLFs than CFPs, demonstrating the impact of applying the pesticides across the fields with planting.

- In hay and pasture fields, pesticide concentrations were higher in CFPs than in OLFs, suggesting transport of pesticides from upgradient, unsampled, row-crop fields through the unamended hay and pasture fields.

- CFPs in riparian buffers and grass pathways located between the row-cropped fields and the stream tended to have lower concentrations than the upland field (OLF-F) but higher concentrations than the buffer OLF, suggesting a potential to reduce pesticide transport in riparian zones by interrupting CFPs leading to the stream.

- CFPs originating from natural springs and seeps are more likely to transport pesticides applied under the soil surface in upgradient fields, while CFPs driven by topographical or animal-driven mechanisms aid in the transport of surface applied pesticides.

Additionally, the relative importance of surface runoff versus subsurface flow transport pathways appeared to be similar for atrazine and metolachlor but different for imidacloprid. This may be due to the application methods for each pesticide. Atrazine and metolachlor are typically applied as sprays directly to the surface. If rainfall occurs after application, any surface runoff would likely mobilize atrazine and metolachlor. Imidacloprid, which is introduced into fields predominantly on seed coatings and has a low organic carbon partition coefficient, can be easily transported via subsurface flow.

Based on the findings of this study, it is possible that CFPs could undermine the performance of riparian buffers in mitigating pesticides present in surface runoff. Investigation of the factors that cause sheet flow to converge and form CFPs would inform adoption of land practices to reduce the likelihood that flow convergence will occur. Overall, this research found that CFPs affect the transport of pesticides in an agricultural setting, but the effect is largely site-specific and dependent on both natural and anthropogenic factors.

\section{ACKNOWLEDGEMENTS}

J. W. Chandler was funded by the Pennsylvania State University Department of Agricultural and Biological Engineering. H. E. Preisendanz, H. A. Elliott, and J. E. Watson are supported, in part, by USDA Grant No. 2017-7701926374 and by the USDA National Institute of Food and Agriculture Federal Appropriations under Project PEN04574 and Accession No. 1004448. H. E. Preisendanz is supported, in part, by the Pennsylvania State University Institutes of Energy and the Environment. The authors express their gratitude to Terry Troutman and Todd Strohecker at the USDA-ARS Klingerstown, Pennsylvania, location for providing soil sampling materials and facilitating access to the field sites, as well as Jim Richards for providing pesticide application information. Additional gratitude is extended to Dr. Cibin Raj, Ryan Barnes, Melanie Nowin, Faith Kibuye, Talia Leventhal, and Kathryn Hayden for their assistance in collecting soil samples in the field, to Tucker Wells and Jamie Weikel for help in extracting soil samples in the lab, and to Eric Hagan for field assistance.

H. E. Preisendanz and J. W. Chandler would each like to acknowledge their respective daughters, Maya Gall and Anna Chandler, for their understanding and patience during the final writing stages of this publication, which occurred during the stay-at-home orders during the COVID-19 pandemic that turned living rooms into home offices at the time the manuscript was due.

Mention of trade names or commercial products in this publication is solely for the purpose of providing specific information and does not imply recommendation or endorsement by The Pennsylvania State University or the USDA.

\section{REFERENCES}

Alford, A., \& Krupke, C. H. (2017). Translocation of the neonicotinoid seed treatment clothianidin in maize. PLoS One, 12(3), e0173836. https://doi.org/10.1371/journal.pone.0173836

Bryant, R. B., Veith, T. L., Feyereisen, G. W., Buda, A. R., Church, C. D., Folmar, G. J., ... Kleinman, P. J. (2011). U.S. Department of Agriculture Agricultural Research Service Mahantango Creek Watershed, Pennsylvania, United States: Physiography and history. Water Resour. Res., 47(8). https://doi.org/10.1029/2010WR010056

CDPR. (2019). Sacramento, CA: California Department of Pesticide Regulation. Retrieved from https://www.cdpr.ca.gov/index.htm

Chandler, J. (2019). Impact of concentrated flow pathways on the movement of pesticides through agricultural fields. MS thesis. University Park, PA: Pennsylvania State University.

de Lima e Silva, C., Brennan, N., Brouwer, J. M., Commandeur, D., Verweij, R. A., \& van Gestel, C. A. M. (2017). Comparative toxicity of imidacloprid and thiacloprid to different species of soil invertebrates. Ecotoxicology, 26(4), 555-564. https://doi.org/10.1007/s10646-017-1790-7

Dodd, R. J., Sharpley, A. N., \& Berry, L. G. (2018). Organic phosphorus can make an important contribution to phosphorus loss from riparian buffers. Agric. Environ. Letters, 3(1), article 180002. https://doi.org/10.2134/ael2018.01.0002

Dosskey, M. G., Helmers, M. J., Eisenhauer, D. E., Franti, T. G., \& Hoagland, K. D. (2002). Assessment of concentrated flow through riparian buffers. J. Soil Water Cons., 57(6), 336-343.

Frame, S. T., Pearsons, K. A., Elkin, K. R., Saporito, L. S., Preisendanz, H. E., Karsten, H. D., \& Tooker, J. F. (2021). Assessing surface and subsurface transport of neonicotinoid insecticides from no-till crop fields. J. Environ. Qual., 50(2), 476-484. https://doi.org/10.1002/jeq2.20185

Hartnett, S., Musah, S., \& Dhanwada, K. R. (2013). Cellular effects of metolachlor exposure on human liver (HepG2) cells. Chemosphere, 90(3), 1258-1266. https://doi.org/10.1016/j.chemosphere.2012.09.077

Hirt, C. C., Veith, T. L., Collick, A. S., Yetter, S. E., \& Brooks, R. P. (2020). Headwater stream condition and nutrient runoff: Relating SWAT to empirical ecological measures in an 
agricultural watershed in Pennsylvania. J. Environ. Qual., 49(3), 557-568. https://doi.org/10.1002/jeq2.20032

Kim, S., Chen, J., Cheng, T., Gindulyte, A., He, J., He, S., ... Bolton, E. E. (2019). PubChem 2019 update: Improved access to chemical data. Nucleic Acids Res., 47(D1), D1102-D1109. https://doi.org/10.1093/nar/gky1033

Klapproth, J. C., \& Johnson, J. E. (2009). Understanding the science behind riparian forest buffers: Effects on water quality. Publication 420-151. Blacksburg, VA: Virginia Cooperative Extension. Retrieved from https://www.pubs.ext.vt.edu/content/dam/pubs_ext_vt_edu/420/ 420-151/420-151_pdf.pdf

Knight, K. W., Schultz, R. C., Mabry, C. M., \& Isenhart, T. M. (2010). Ability of remnant riparian forests, with and without grass filters, to buffer concentrated surface runoff. JAWRA, 46(2), 311-322. https://doi.org/10.1111/j.17521688.2010.00422.X

Li, H., Feng, Y., Li, X., \& Zeng, D. (2018). Analytical confirmation of various herbicides in drinking water resources in sugarcane production regions of Guangxi, China. Bull. Environ. Contam. Toxicol., 100(6), 815-820. https://doi.org/10.1007/s00128-0182324-6

Lin, H. S., Kogelmann, W., Walker, C., \& Bruns, M. A. (2006). Soil moisture patterns in a forested catchment: A hydropedological perspective. Geoderma, 131, 345-368. https://doi.org/10.1016/j.geoderma.2005.03.013

Lipton, D. (2019). Economic benefits of a restored oyster fishery in Chesapeake Bay. J. Shellfish Res., 27(3), 619-623. https://doi.org/10.2983/07308000(2008)27[619:EBOARO]2.0.CO;2

Liu, Y., Engel, B. A., Flanagan, D. C., Gitau, M. W., McMillan, S. K., \& Chaubey, I. (2017). A review on effectiveness of best management practices in improving hydrology and water quality: Needs and opportunities. Sci. Total Environ., 601-602, 580-593. https://doi.org/10.1016/j.scitotenv.2017.05.212

Lyons, J., Thimble, S. W., \& Paine, L. K. (2000). Grass versus trees: Managing riparian areas to benefit streams of central North America. JAWRA, 36(4), 919-930. https://doi.org/10.1111/j.1752-1688.2000.tb04317.x

Minitab. (2019). Minitab ver. 19.1.1. State College, PA: Minitab, Inc. Retrieved from www.minitab.com

Myers, J. L., Wagger, M. G., \& Leidy, R. B. (1995). Chemical movement in relation to tillage system and simulated rainfall intensity. J. Environ. Qual., 24(6), 1183-1192. https://doi.org/10.2134/jeq1995.00472425002400060019x

NCDC. (2020). National Centers for Environmental Information. Asheville, NC: National Climatic Data Center. Retrieved from https://www.ncdc.noaa.gov

Pignatello, J. J., \& Huang, L. Q. (1991). Sorptive reversibility of atrazine and metolachlor residues in field soil samples. $J$. Environ. Qual., 20(1), 222-228. https://doi.org/10.2134/jeq1991.00472425002000010035x

Pionke, H. B., \& Glotfelty, D. W. (1990). Contamination of groundwater by atrazine and selected metabolites. Chemosphere, 21(6), 813-822. https://doi.org/10.1016/0045-6535(90)90268-X

Puckett, L. J. (2004). Hydrogeologic controls on the transport and fate of nitrate in groundwater beneath riparian buffer zones: Results from thirteen studies across the United States. Water Sci. Tech., 49(3), 47-53. https://doi.org/10.2166/wst.2004.0160

Reungsang, A., Moorman, T. B., \& Kanwar, R. S. (2005). Prediction of atrazine fate in riparian buffer strips soils using the Root Zone Water Quality Model. J. Water Environ. Tech., 3(2), 209-222. https://doi.org/10.2965/jwet.2005.209

Salazar-Ledesma, M., Prado, B., Zamora, O., \& Siebe, C. (2018). Mobility of atrazine in soils of a wastewater irrigated maize field. Agric. Ecosyst. Environ., 255, 73-83. https://doi.org/10.1016/j.agee.2017.12.018

Sheets, L. P. (2010). Chapter 95: Imidacloprid: A neonicotinoid insecticide. In R. Krieger (Ed.), Hayes' handbook of pesticide toxicology (3rd Ed., pp. 2055-2064). New York, NY: Academic Press. https://doi.org/10.1016/B978-0-12-374367-1.00095-1

Shelley, L. K., Ross, P. S., Miller, K. M., Kaukinen, K. H., \& Kennedy, C. J. (2012). Toxicity of atrazine and nonylphenol in juvenile rainbow trout (Oncorhynchus mykiss): Effects on general health, disease susceptibility, and gene expression. Aquat. Toxicol., 124-125, 217-226. https://doi.org/10.1016/j.aquatox.2012.08.007

Shen, H., Wen, L., He, Y., Hu, W., Li, H., Che, X., \& Li, X. (2018). Rainfall and inflow effects on soil erosion for hillslopes dominated by sheet erosion or rill erosion in the Chinese Mollisol region. J. Mountain Sci., 15(10), 2182-2191. https://doi.org/10.1007/s11629-018-5056-5

Sheridan, J. M., Lowrance, R., \& Bosch, D. D. (1999). Management effects on runoff and sediment transport in riparian forest buffers. Trans. ASAE, 42(1), 55-64. https://doi.org/10.13031/2013.13214

Shrestha, P., Williard, K. W., Schoonover, J. E., \& Park, L. (2018). Prevalence of concentrated flow paths in agricultural fields in southern Illinois. Water Air Soil Pollut., 229(6), 198. https://doi.org/10.1007/s11270-018-3841-y

USDA. (2019). Web soil survey. Washington, DC: USDA Natural Resources Conservation Service. Retrieved from https://websoilsurvey.sc.egov.usda.gov/App/HomePage.htm

USDA. (2020). Riparian forest buffers. Washington, DC: USDA National Agroforestry Center. Retrieved from https://www.fs.usda.gov/nac/practices/riparian-forestbuffers.php

Wallace, C. W., McCarty, G., Lee, S., Brooks, R. P., Veith, T. L., Kleinman, P. J. A., \& Sadeghi, A. M. (2018). Evaluating concentrated flowpaths in riparian forest buffer contributing areas using LiDAR imagery and topographic metrics. Remote Sensing, 10(4), article 614. https://doi.org/10.3390/rs10040614

Wan, M. T., Buday, C., Schroeder, G., Kuo, J., \& Pasternak, J. (2006). Toxicity to Daphnia magna, Hyalella azteca, Oncorhynchus kisutch, Oncorhynchus mykiss, Oncorhynchus tshawytscha, and Rana catesbeiana of atrazine, metolachlor, simazine, and their formulated products. Bull. Environ. Contam. Toxicol., 76(1), 52-58. https://doi.org/10.1007/s00128-005-0888-4

Zhang, X., Liu, X., Zhang, M., Dahlgren, R. A., \& Eitzel, M. (2010). A review of vegetated buffers and a meta-analysis of their mitigation efficacy in reducing nonpoint-source pollution. J. Environ. Qual., 39(1), 76-84. https://doi.org/10.2134/jeq2008.0496

\section{NOMENCLATURE}

$\mathrm{BMP}=$ best management practice

$\mathrm{CFP}=$ concentrated flow pathway

CFP-F = concentrated flow pathway sample in agricultural field (row-cropped, pasture, or hay)

$\mathrm{CFP}-\mathrm{R}=$ concentrated flow pathway sample in riparian buffer

LOD $=$ limit of detection

LOQ = limit of quantification

$\mathrm{MH}=$ Mahantango Creek watershed

OLF $=$ overland flow

OLF-F $=$ overland flow sample in agricultural field (rowcropped, pasture, or hay)

OLF-R = overland flow sample in riparian buffer 